DOI: $10.21802 / \mathrm{artm} .2020 .1 .13 .36$.

УДК 636.09:001.893:[57.083.32:613.26/.28:577.2]

\title{
АНАЛІЗ ДІАГНОСТИЧНИХ ПАРАМЕТРІВ ІМУНОБЛОТІНГУ РІЗНИХ ВИРОБНИКІВ ДЛЯ ВИЗНАЧЕННЯ СЕНСИБІЛІЗАЦІЇ ДО КЛШЩОВИХ ТА ЕПІДЕРМАЛЬНИХ АЛЕРГЕНІВ У ПАЦІЕНТІВ 3 РЕСПІРАТОРНИМИ АЛЕРГІЧНИМИ ЗАХВОРЮВАННЯМИ
}

\author{
А.С. Богомолов ${ }^{1}$, С.В. Зайков ${ }^{2}$ \\ ${ }^{1}$ Вінницький національний медичний університет ім. М.І. Пирогова, кафедра фтизіатрї з курсом \\ клінічної імунології та алергології, м. Вінниия, Украӥна, \\ ORCID ID: 0000-0002-5336-4858, e-mail: art.bogomolov@gmail.com, \\ ${ }^{2}$ Національна медична академія післядипломної освіти ім. П.Л. Шупика, кафедра фтизіатрії \\ та пульмонології, м. Київ, Україна, ORCID ID: 0000-0002-9276-0490, e-mail: zaikov1960@gmail.com
}

Резюме. Метою дослідження було порівняти діагностичні параметри різних систем серологічного дослідження методом імуноблоту для визначення сенсибілізації до алергенів кліщової та епідермальної груп у пацієнтів з респіраторними алергічними захворюваннями - алергічним ринітом та бронхіальною астмою.

Матеріали та методи. У ході дослідження 88 пацієнтів з алергічним ринітом та / або атопічною астмою були обстежені трьома різними методами специфічної алергічної діагностики (in vivo та in vitro). Критеріями включення були діагноз алергічного риніту (як інтермітуючого, так і персистуючого) та / або атопічної астми. Прик-тест проводився за класичною методикою тестування відповідно до нормативних документів 3 комерційними екстрактами алергенів. Вестерн-блот для визначення рівнів IgЕ проводили з використанням тестсистем RIDA AllergyScreen (R-Biopharm AG, Дармштадт, Німеччина) і Euroline (Euroimmun).

Результати дослідження та їх обговорення. Результати двох систем визначення специфічного IgE до алергенів кліщової та епідермальної груп методами Rida AllergyScreen тa Euroline не завжди дуже добре узгоджуються між собою внаслідок значного систематичного розходження показників.

Результати визначення специфічних IgE до окремих алергенів добре узгоджуються між собою, втім до епідермальних алергенів шерсті кролика та морської свинки обидва методи не узгоджуються з результатами шкірного тестування методом прик-тесту, даючи хибно-негативні результати. Подальший аналіз узгодженості та діагностичних параметрів методів по інших групах алергенів $є$ необхідним для узагальнення усіх результатів дослідження.

Ключові слова: прик-тест, алергія, імуноблотинг, IgE.

Вступ. Традиційно діагностика алергічних захворювань заснована на послідовному застосуванні ряду методів дослідження: клініко-анамнестичного (збір скарг та анамнезу), фізікального, шкірних тестів 3 алергенами, провокаційних проб та лабораторних методів [1].

Імуноблотінг (імуноблот) $є$ високоспецифічним і високочутливим референтним методом, який $\epsilon$ корисним у діагнозі для пацієнтів з позитивними або невизначеними результатами аналізів, отриманих у тому числі за допомогою реакції пасивної гемаглютинації або імуноферментного аналізу $[2,3]$. Цей метод виявлення антитіл до окремих алергенів заснований на постановці імуноферментного аналізу на нітроцелюлозних мембранах, на які у вигляді окремих смуг нанесено специфічні білки, розділені гельелектрофорезом. У тому випадку, коли $є$ антитіла проти певних антигенів, з'являється видима темна лінія у відповідному локусі стрипа. Унікальність імуноблоту полягає в його високій інформативності й достовірності отриманих результатів. При проведенні дослідження використовують набори двох типів вестерн-блот і лайн-блот.

Набори вестерн-блот містять тестові стрипмембрани з електрофоретично розділеними нативними антигенами відповідних алергенів у порядку їх молекулярної маси. На мембрани можуть бути також нанесені 1-2 додаткові лінії 3 клінічно значущими антигенами (вестерн-, лайнблот) [4-7].

Обгрунтування дослідження. За останні роки кількість виробників реактивів для проведення процедури імуноблоту зросла, i, відповідно, зросли доступність та частота використання методу у повсякденній практиці лікаря-алерголога. Одним із недоліків методу є його напівкількісність, що передбачає кінцеву оцінку висушених стріпів за допомогою фотометричних технік. Від якості оцінки, наявності калібрувальних кривих, розподільчої здатності обладнання певною мірою може залежати результат дослідження, який в подальшому інтерпретується лікарем та впливає на призначення лікування.

Наше дослідження направлене на визначення діагностичних параметрів імуноблоту різних виробників у порівнянні з класичним прик-тестом у розрізі визначення сенсибілізації до кліщових та епідермальних алергенів.

Мета дослідження. Метою нашого дослідження було порівняти діагностичні параметри різних систем серологічного дослідження методом імуноблоту для визначення сенсибілізації до алергенів кліщової та епідермальної груп у пацієнтів з респіра- 
торними алергічними захворюваннями - алергічним ринітом та бронхіальною астмою.

Матеріали та методи. У процесі цього дослідження трьома різними методами специфічної алергологічної діагностики (in vivo та in vitro) було обстежено 88 пацієнтів, хворих на бронхіальну астму та алергічний риніт. Дослідження було відкритим, проспективним, порівняльним.

Шкірне тестування проводили стандартизованим методом прик-тесту за допомогою ланцетів вітчизняними алергенами виробництва Вінницького МП «Імунолог». Техніка постановки шкірних тестів та оцінювання результатів шкірного тестування проводили відповідно до наказу MO3 і АMH України № 127/18 від 02.04.2002 р. «Про організаційні заходи по впровадженню сучасних технологій діагностики та лікування алергічних захворювань».

Кількісне визначення специфічних IgE в сироватці крові проводили за допомогою методу імуноблоту «Euroimmun» (Milenia Biotec $\mathrm{GmbH}$, Німеччина) та імуноблоту «RIDA $®$ AllergyScreen» (RBiopharm AG, Німеччина) у відповідності до методик

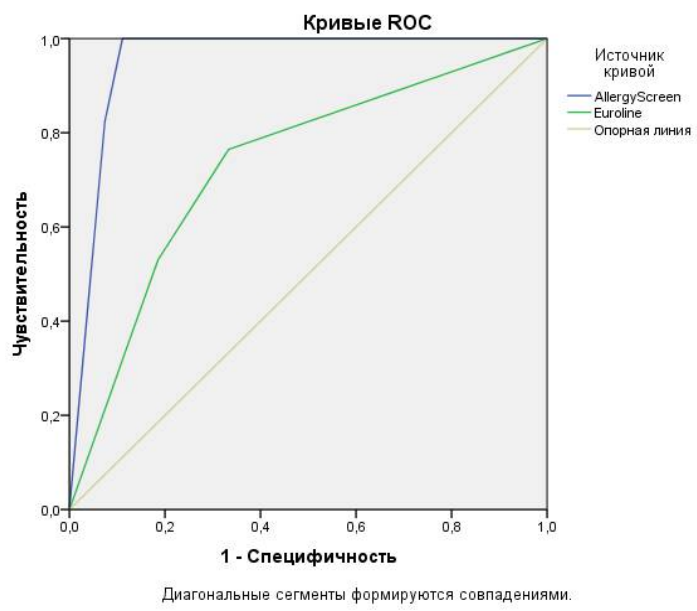

Pис. 1. ROC-крива для виявлення специфічного IgE методами AllergyScreen та Euroline для визначення сенсибілізації до алергену D. Pteronyssinus проведення таких досліджень 3 інструкцій виробників.

Статистичну обробку результатів, побудову діаграм та розподілів значень статистичного аналізу було виконано за допомогою програмного пакету IBM SPSS Statistics 21.

Результати дослідження. У процесі цього дослідження трьома різними методами специфічної алергологічної діагностики (in vivo та in vitro) було обстежено 88 пацієнтів, хворих на бронхіальну астму та алергічний риніт.

Для якісного аналізу діагностичної значимості методів було використано ROC - аналіз, який являє собою побудову графіка залежності чутливості методу від відносної кількості хибнонегативних результатів. Графік ROC-кривої для виявлення специфічного IgE методами AllergyScreen та Euroline для визначення сенсибілізації до алергену D. Pteronyssinus та алергену D. farinae наведено на рисунку 1 і рисунку 2 відповідно.

Результати кількісної оцінки побудованої кривої за допомогою обчислення площі AUC для D. Pteronyssinus наведено у таблиці 1.

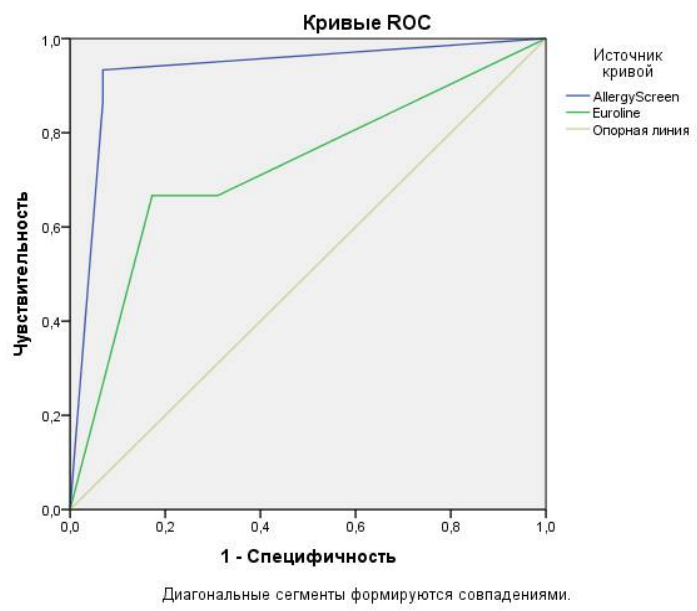

Pис. 2. ROC-крива для виявлення специфічного IgE методами AllergyScreen тa Euroline для визначення сенсибілізації до алергену D. farina

Таблиця 1

Результати статистичної оцінки ROC-кривої для виявлення специфічного IgE методами AllergyScreen та Euroline для визначення сенсибілізації до алергену D. Pteronyssinus

\begin{tabular}{|c|c|c|c|c|c|}
\hline \multirow[t]{2}{*}{ Тестові змінні } & \multirow[t]{2}{*}{ Площа } & \multirow[t]{2}{*}{$\begin{array}{c}\text { Стандартна } \\
\text { похибка }\end{array}$} & \multirow{2}{*}{$\begin{array}{c}\text { Асимптотична } \\
\text { значимість } \\
\text { нульової } \\
\text { гіпотези }\end{array}$} & \multicolumn{2}{|c|}{$\begin{array}{c}\text { Асимптотичний } 95 \text { \% довірчий } \\
\text { інтервал }\end{array}$} \\
\hline & & & & Нижня межа & Верхня межа \\
\hline AllergyScreen & 0,953 & 0,023 & 0,000 & 0,907 & 0,999 \\
\hline Euroline & 0,733 & 0,056 & 0,000 & 0,624 & 0,843 \\
\hline
\end{tabular}

За результатами оцінки кривої виявлення специфічного IgE методом AllergyScreen для визначення сенсибілізації до алергену D. Pteronyssinus має відмінну діагностичну значимість (AUC=0,953), виявлення специфічного IgE методом Euroline для визначення сенсибілізації до алергену D. Pteronyssinus - добру діагностичну значимість (AUC=0,733). В обидвох випадках асимптотична значимість доводить відсутність погодження нульової гіпотези (при якій істинна площа рівна 0,5$)$ та достовірність значень площі AUC. 
Результати кількісної оцінки побудованої кривої за допомогою обчислення площі АUC для алергену D. farinae наведено у таблиці 2.

Таблиця 2

Результати статистичної оцінки ROC-кривої для виявлення специфічного IgE методами AllergyScreen тa Euroline для визначення сенсибілізації до алергену D. farinae

\begin{tabular}{|l|c|c|c|c|c|}
\hline Тестові змінні & Площа & \multirow{2}{*}{$\begin{array}{c}\text { Стандартна } \\
\text { похибка }\end{array}$} & \multirow{2}{*}{$\begin{array}{c}\text { Асимптотична } \\
\text { значимість }\end{array}$} & \multicolumn{2}{|c|}{$\begin{array}{c}\text { Асимптотичний 95 \% } \\
\text { довірчий інтервал }\end{array}$} \\
\cline { 5 - 6 } & & & нульової гіпотези & Нижня межа & Верхня межа \\
\hline AllergyScreen & 0,930 & 0,033 & 0,000 & 0,865 & 0,995 \\
\hline Euroline & 0,724 & 0,061 & 0,001 & 0,604 & 0,844 \\
\hline
\end{tabular}

За результатами оцінки кривої виявлення специфічного IgE методом AllergyScreen для визначення сенсибілізації до алергену D. farinae має відмінну діагностичну значимість (AUC=0,930), виявлення специфічного IgE методом Euroline для визначення сенсибілізації до алергену D. farinae - добру діагностичну значимість (AUC=0,724). В обидвох випадках асимптотична значимість доводить відсутність погодження нульової гіпотези (при якій істинна площа рівна 0,5) та достовірність значень площі AUC.

Для якісного аналізу діагностичної значимості методів було використано ROC - аналіз, який являє собою побудову графіка залежності чутливості методу від відносної кількості хибнонегативних результатів. Графік ROC-кривої для виявлення специфічного IgЕ методами AllergyScreen та Euroline для визначення сенсибілізації до алергену шерсті кішки наведено на рисунку 3.

Результати кількісної оцінки побудованої кривої за допомогою обчислення площі AUC наведено у таблиці 3.

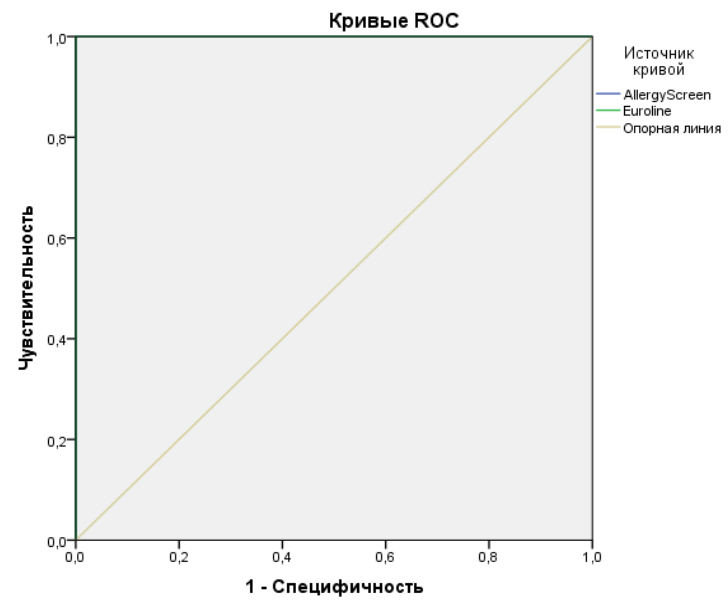

Pис. 3. ROC-крива для виявлення специфічного IgE методами AllergyScreen тa Euroline для визначення сенсибілізації до алергену шерсті кішки
За результатами оцінки кривої виявлення специфічного IgE методом AllergyScreen для визначення сенсибілізації до алергену шерсті кішки має відмінну діагностичну значимість $(\mathrm{AUC}=1,0)$, виявлення специфічного IgE методом Euroline для визначення сенсибілізації до алергену шерсті кішки - відмінну діагностичну значимість $(\mathrm{AUC}=1,0)$.

В обидвох випадках асимптотична значимість доводить відсутність погодження нульової гіпотези (при якій істинна площа рівна 0,5) та достовірність значень площі AUC.

Графік ROC-кривої для виявлення специфічного IgE методами AllergyScreen та Euroline для визначення сенсибілізації до алергену лупи коня наведено на рисунку 4.

Результати кількісної оцінки побудованої кривої за допомогою обчислення площі AUC наведено у таблиці 4.

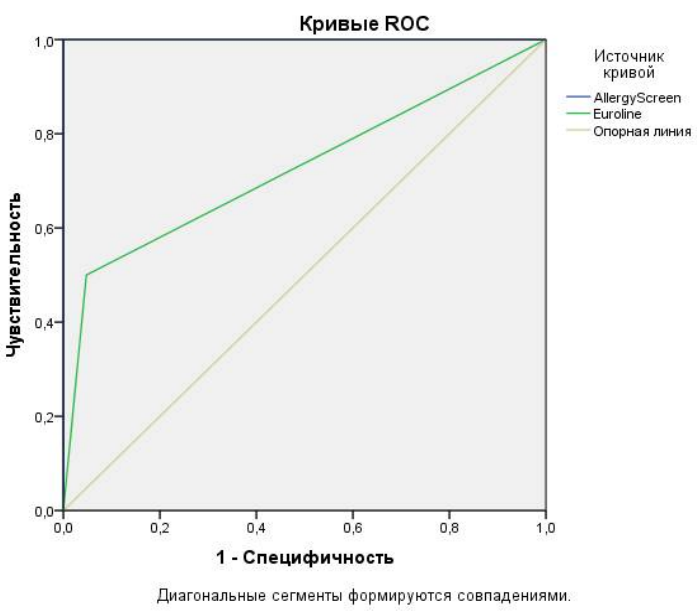

Рис. 4. ROC-крива для виявлення специфічного IgE методами AllergyScreen та Euroline для визначення сенсибілізації до алергену лупи коня

Таблиця 3

Результати статистичної оцінки ROC-кривої для виявлення специфічного IgE методами AllergyScreen та Euroline для визначення сенсибілізації до алергену шерсті кішки

\begin{tabular}{|l|c|c|c|c|c|}
\hline \multicolumn{1}{|c|}{ Тестові змінні } & Площа & $\begin{array}{c}\text { Стандартна } \\
\text { похибка }\end{array}$ & $\begin{array}{c}\text { Асимптотична } \\
\text { значимість }\end{array}$ & $\begin{array}{c}\text { Асимптотичний 95 \% довірчий } \\
\text { інтервал }\end{array}$ \\
\cline { 4 - 6 } & & & Нижня межа & Верхня межа \\
\hline AllergyScreen & 1,000 & 0,000 & 0,000 & 1,000 & 1,000 \\
\hline Euroline & 1,000 & 0,000 & 0,000 & 1,000 & 1,000 \\
\hline
\end{tabular}


Таблиця 4

Результати статистичної оцінки ROC-кривої для виявлення специфічного IgE методами AllergyScreen та Euroline для визначення сенсибілізації до алергену лупи коня

\begin{tabular}{|l|c|c|c|c|c|}
\hline \multicolumn{1}{|c|}{ Тестові змінні } & Площа & $\begin{array}{c}\text { Стандартна } \\
\text { похибка }\end{array}$ & $\begin{array}{c}\text { Асимптотична } \\
\text { значимість }\end{array}$ & $\begin{array}{c}\text { Асимптотичний 95 \% довірчий } \\
\text { інтервал }\end{array}$ \\
\cline { 4 - 6 } & & & & Нижня межа & Верхня межа \\
\hline AllergyScreen & 1,000 & 0,000 & 0,001 & 1,000 & 1,000 \\
\hline Euroline & 0,726 & 0,160 & 0,128 & 0,412 & 1,000 \\
\hline
\end{tabular}

За результатами оцінки кривої виявлення специфічного IgE методом AllergyScreen для визначення сенсибілізації до алергену лупи коня має відмінну діагностичну значимість $(\mathrm{AUC}=1,0)$, виявлення специфічного IgE методом Euroline для визначення сенсибілізації до алергену лупи коня - добру діагностичну значимість (AUC=0,726). У випадку виявлення специфічного IgE методом Euroline для визначення сенсибілізації до алергену лупи коня асимптотична значимість доводить погодження нульової гіпотези, при якій істинна площа рівна 0,5 .

Графік ROC-кривої для виявлення специфічного IgE методами AllergyScreen та Euroline для визначення сенсибілізації до алергену шерсті собаки наведено на рисунку 5.

Результати кількісної оцінки побудованої кривої за допомогою обчислення площі AUC наведено у таблиці 5

За результатами оцінки кривої виявлення специфічного IgE методом AllergyScreen для визначення сенсибілізації до алергену шерсті собаки має відмінну діагностичну значимість ( $\mathrm{AUC}=0,988)$, виявлення специфічного IgE методом Euroline для визначення сенсибілізації до алергену шерсті собаки добру діагностичну значимість $(\mathrm{AUC}=0,725)$. В обидвох випадках асимптотична значимість доводить відсутність погодження нульової гіпотези (при якій істинна площа рівна 0,5) та достовірність значень площі AUC.

Графік ROC-кривої для виявлення специфічного IgE методами AllergyScreen та Euroline для визначення сенсибілізації до алергену шерсті хом'яка наведено на рисунку 6.

Результати кількісної оцінки побудованої кривої за допомогою обчислення площі AUC наведено у таблиці 6.

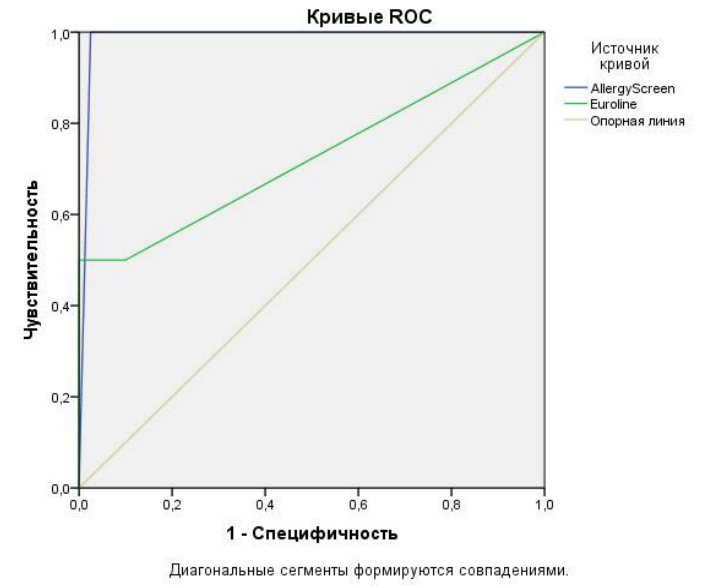

Рис. 5. ROC-крива для виявлення специфічного IgE методами AllergyScreen та Euroline для визначення сенсибілізації до алергену шерсті собаки

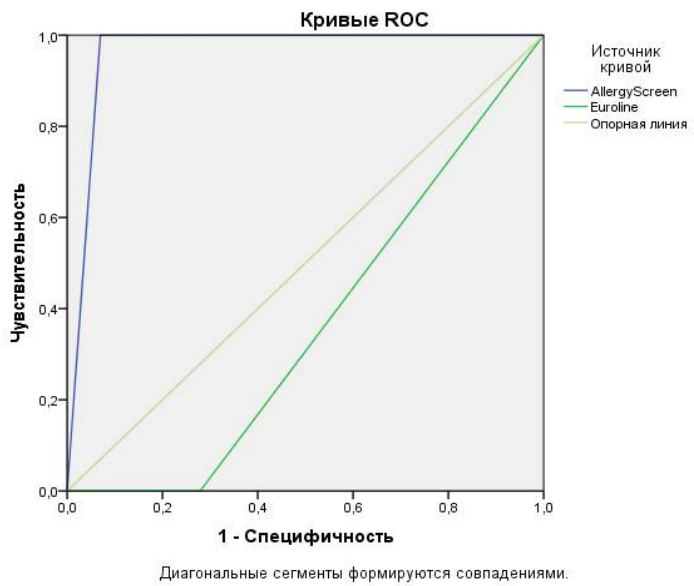

Pис. 6. ROC-крива для виявлення специфічного IgE методами AllergyScreen тa Euroline для визначення сенсибілізації до алергену шерсті хом'яка

Таблиця 5 Результати статистичної оцінки ROC-кривої для виявлення специфічного IgE методами AllergyScreen та Euroline для визначення сенсибілізації до алергену шерсті собаки

\begin{tabular}{|l|c|c|c|c|c|}
\hline \multicolumn{1}{|c|}{ Тестові змінні } & Площа & $\begin{array}{c}\text { Стандартна } \\
\text { похибка }\end{array}$ & $\begin{array}{c}\text { Асимптотична } \\
\text { значимість }\end{array}$ & $\begin{array}{c}\text { Aсимптотичний 95 \% довірчий } \\
\text { інтервал }\end{array}$ \\
\cline { 4 - 6 } & & & 0,000 & 0,966 & Верхня межа \\
\hline AllergyScreen & 0,988 & 0,011 & 0,037 & 0,492 & 0,958 \\
\hline Euroline & 0,725 & 0,119 & Нижня & \\
\hline
\end{tabular}


Таблиця 6

Результати статистичної оцінки ROC-кривої для виявлення специфічного IgE методами AllergyScreen та Euroline для визначення сенсибілізації до алергену шерсті хом'яка

\begin{tabular}{|l|c|c|c|c|c|}
\hline Тестові змінні & Площа & $\begin{array}{c}\text { Стандартна } \\
\text { похибка }\end{array}$ & $\begin{array}{c}\text { Асимптотична } \\
\text { значимість }\end{array}$ & $\begin{array}{c}\text { Асимптотичний 95 \% довірчий } \\
\text { інтервал }\end{array}$ \\
\cline { 4 - 6 } & & & Нижня межа & Верхня межа \\
\hline AllergyScreen & 0,965 & 0,023 & 0,025 & 0,920 & 1,000 \\
\hline Euroline & 0,360 & 0,153 & 0,502 & 0,061 & 0,660 \\
\hline
\end{tabular}

За результатами оцінки кривої виявлення специфічного IgE методом AllergyScreen для визначення сенсибілізації до алергену шерсті хом'яка має відмінну діагностичну значимість $(\mathrm{AUC}=0,965)$, виявлення специфічного IgE методом Euroline для визначення сенсибілізації до алергену шерсті хом'яка незадовільну діагностичну значимість (AUC=0,360). $\mathrm{y}$ випадку виявлення специфічного $\operatorname{IgE}$ методом Euroline асимптотична значимість доводить погодження нульової гіпотези (при якій істинна площа рівна або менше 0,5$)$.

У випадках виявлення специфічного IgE методами AllergyScreen та Euroline для визначення сенсибілізації до алергену шерсті кролика та алергену шерсті морської свинки діагностична значимість незадовільна та ROC-криві побудувати неможливо через відсутність погодженості результатів серологічних методів та шкірного тестування методом приктесту. таблиця 7.

Узагальнені результати аналізу наведено в

Обговорення результатів. Отримані нами результати чітко показують, що при порівнянні обох блот - систем для визначення специфічних $\operatorname{IgE}$ до алергенів різних груп не завжди добре узгоджуються між собою. Як ми вже вказували раніше, метод вестерн-блотінгу є напівкількісним, а, отже, може мати певні об'єктивні труднощі оцінювання на кінцевому етапі аналізу (а саме при оцінці готових висушених стріпів).
Втім, серед означених проблем найбільш суттєвими є дві: систематичне розходження показників та хибнонегативні / хибнопозитивні результати. Перша створює небезпеку невірної інтерпретації результатів визначення клінічно значущої сенсибілізації, а друга - небезпеку повноцінно невірної діагностики. На нашу думку, метод імуноблотінгу має використовуватись на другому етапі діагностики у випадках відсутності протипоказів до виконання шкірних проб та, з урахуванням вищеозначеного, на першому етапі у випадку, якщо такі протипокази дійсно існують.

Висновки. Таким чином, результати двох систем визначення специфічного IgE до алергенів кліщової та епідермальної груп методами Rida AllergyScreen та Euroline не завжди дуже добре узгоджуються між собою внаслідок значного систематичного розходження показників.

Результати визначення специфічних $\operatorname{IgE}$ до окремих алергенів добре узгоджуються між собою, втім до епідермальних алергенів шерсті кролика та морської свинки обидва методи не узгоджуються 3 результатами шкірного тестування методом приктесту, даючи хибно-негативні результати. Подальший аналіз узгодженості та діагностичних параметрів методів по інших групах алергенів є необхідним для узагальнення усіх результатів дослідження.

Результати статистичного аналізу порівняння діагностичної значимості визначення специфічного IgE до кліщових та епідермальних алергенів методами AllergyScreen та Euroline

\begin{tabular}{|c|c|c|}
\hline & AllergyScreen & Euroline \\
\hline Відмінна & $\begin{array}{l}\text { Шерсть хомяка } \\
\text { Шерсть собаки } \\
\text { Лупа коня } \\
\text { Шерсть кішки } \\
\text { D. farinae } \\
\text { D. Pteronissinus }\end{array}$ & Шерсть кішки \\
\hline Добра & & $\begin{array}{c}\text { Шерсть собаки } \\
\text { Лупа коня } \\
\text { D. farinae } \\
\text { D. Pteronissinus }\end{array}$ \\
\hline Незадовільна & $\begin{array}{c}\text { Шерсть морської свинки } \\
\text { Шерсть кролика }\end{array}$ & $\begin{array}{c}\text { Шерсть морської свинки } \\
\text { Шерсть кролика } \\
\text { Шерсть хомяка }\end{array}$ \\
\hline
\end{tabular}

References:

1. Zaikov SV, Bogomolov AYe. Sovremennye podhody $\mathrm{k}$ laboratorniy diagnostike allergicheskih zabolevaniy. Novosti mediciny i farmatsii. 2013; 14(465):45-50.
2. Casset A, Khayath N, de Blay F. How In Vitro Assays Contribute to Allergy Diagnosis. Curr Allergy Asthma Rep. 2016, Nov; 16(11):82.

3. Chauveau A. Disagreement between Skin Prick Tests and Specific IgE in Early Childhood. Int Arch Allergy 
Immunol. 2016; 170(2):69-74. doi: 10.1159/ 000446776. Epub 2016 Jul 26.

4. García-Solaesa V, Abad SC. SDS-Polyacrylamide Electrophoresis and Western Blotting Applied to the Study of Asthma. Methods Mol Biol. 2016; 1434:107-120. doi:10.1007/978-1-4939-3652-6 8.

5. Hnasko TS, Hnasko RM. The Western Blot. Methods Mol Biol. 2015; 1318:87-96. doi:10.1007/978-14939-2742-5_9.

6. Kim B. Western Blot Techniques. Methods Mol Biol. 2017; 1606:133-139. doi:10.1007/978-1-4939-699069.

7. Kurien BT, Dorri Y, Dillon S, Dsouza A, Scofield $\mathrm{RH}$. An overview of Western blotting for determining antibody specificities for immunohistochemistry. Methods Mol Biol. 2011; 717:55-67. doi:10.1007/ 978-1-61779-024-9_3.

УДК 636.09:001.893:[57.083.32:613.26/.28:577.2]

\section{АНАЛИЗ ДИАГНОСТИЧЕСКИХ ПАРАМЕТРОВ ИММУНОБЛОТТИНГА РАЗНЫХ ПРОИЗВО- ДИТЕЛЕЙ ДЛЯ ОПРЕДЕЛЕНИЯ СЕНСИБИЛИ- ЗАЦИИ К КЛЕЩЕВЫМ И ЭПИДЕРМАЛЬНЫМ АЛЛЕРГЕНАМ У ПАЦИЕНТОВ С РЕСПИРАТОРНЫМИ АЛЛЕРГИЧЕСКИМИ ЗАБОЛЕВАНИЯМИ}

\author{
А.Е. Богомолов ${ }^{1}$, С.В. Зайков ${ }^{2}$ \\ ${ }^{1}$ Винницкий национальный медицинский университет \\ им. Н.И. Пирогова, кафедра фтизиатрии с курсом \\ клинической иммунологии и аллергологии, \\ 2. Винница, Украина, \\ ORCID ID: 0000-0002-5336-4858, \\ e-mail: art.bogomolov@gmail.com \\ ${ }^{2}$ Национальная медицинская академия последиплом- \\ ного образования им. П.Л. Шупика, кафедра \\ фттизитрии та пульмонологии, г. Киев, Украина, \\ ORCID ID: 0000-0002-9276-0490, \\ e-mail: zaikov1960@gmail.com
}

Резюме. Целью исследования было сравнить диагностические параметры различных систем серологического исследования методом иммуноблота для определения сенсибилизации к аллергенам клещевой и эпидермальной групп у пациентов с респираторными аллергическими заболеваниями - аллергическим ринитом и бронхиальной астмой.

Материалы и методы. В ходе исследования 88 пациентов с аллергическим ринитом и / или атопической астмой были обследованы тремя различными методами специфической аллергической диагностики (in vivo и in vitro). Критериями включения были диагноз аллергического ринита (как интермиттирующего, так и персистирующего) и / или атопической астмы. Прик-тест проводился по классической методике тестирования в соответствии с нормативными документами с коммерческими экстрактами аллергенов. Вестерн-блот для определения уровней $\operatorname{IgE}$ проводили с использованием тест-систем RIDA
AllergyScreen (R-Biopharm AG, Дармштадт, Германия) и Euroline (Euroimmun).

Результаты исследования и их обсуждение. Результаты двух систем определения специфического $\operatorname{IgE~к~аллергенам~клещевой~и~эпидермальной~групп~}$ методами Rida AllergyScreen и Euroline не всегда очень хорошо согласуются между собой вследствии значительного систематического различия показателей.

Результаты определения специфических $\operatorname{IgE}$ к отдельным аллергенам хорошо согласуются между собой, впрочем у эпидермальных аллергенов шерсти кролика и морской свинки оба метода не согласуются с результатами кожного тестирования методом приктеста, давая ложно-отрицательные результаты. Дальнейший анализ согласованности и диагностических параметров методов по другим группам аллергенов необходим для обобщения всех результатов исследования.

Ключевые слова: прик-тест, аллергия, имуноблотинг, IgE.

UDC 636.09:001.893:[57.083.32:613.26/.28:577.2]

DIAGNOSTIC PARAMETERS ANALYSIS OF THE IMMUNOBLOTING OF DIFFERENT MANUFACTURERS FOR DETERMINATION OF SENSITIZATION TO PATIENTS AND EPIDERMAL ALLERGENS IN PATIENTS WITH RESPIRATORY ALLERGIC DISEASES

\author{
A.Ye. Bogomolov ${ }^{1}$, S.V. Zaikov ${ }^{2}$ \\ ${ }^{1}$ Vinnitsa National Pirogov memorial Medical University, \\ Department of Phythisiology with a course of clinical \\ immunology and allergology, Vinnitsa, Ukraine, \\ ORCID ID: 0000-0002-5336-4858, \\ e-mail: art.bogomolov@gmail.com \\ ${ }^{2}$ Shupyk National Medical Academy of Postgraduate \\ Education, Department of Phythisiology and \\ Pulmonology, Kiev, Ukraine, \\ ORCID ID: 0000-0002-9276-0490, \\ e-mail:zaikov1960@gmail.com
}

Abstract. The aim of the study was to compare the diagnostic parameters of different systems of serological examination by immunoblot method for the determination of sensitization to allergens of tick and epidermal groups in patients with respiratory allergic diseases - allergic rhinitis and bronchial asthma.

Materials and methods. In the study, 88 patients with allergic rhinitis and / or atopic asthma were examined with three different methods of specific allergic diagnosis (in vivo and in vitro). Inclusion criteria were a diagnosis of allergic rhinitis (both intermittent and persistent) and / or atopic asthma. The prick-test was conducted according to the classic test method according to the normative documents with commercial allergen extracts. Western blots for the determination of $\operatorname{IgE}$ levels were performed using RIDA AllergyScreen test systems 
(R-Biopharm AG, Darmstadt, Germany) and Euroline (Euroimmun).

Results and discussion. For the qualitative analysis of the diagnostic significance of the methods, ROC analysis was used, which is a plot of the sensitivity of the method to the relative number of false-negative results.

According to the results of the curve of detection of specific IgE by AllergyScreen method for determination of sensitization to allergen D. farinae has excellent diagnostic significance (AUC $=0,930$ ), detection of specific IgE by Euroline method for determination of sensitization to allergen $\mathrm{D}$. farinae - good diagnostic significance $(\mathrm{AUC}=0,724)$ In both cases, the asymptotic significance is proved by the lack of agreement of the null hypothesis (in which the true area is equal to 0.5 ) and the reliability of the values of the AUC area.

According to the results of the curve of detection of specific IgE by AllergyScreen method for the determination of sensitization to cat allergen has excellent diagnostic significance $(\mathrm{AUC}=1,0)$, detection of specific $\operatorname{IgE}$ by the Euroline method for determination of sensitization to cat allergen - excellent diagnostic significance (AUC = $1,0)$. In both cases, the asymptotic significance is proved by the lack of agreement of the null hypothesis (in which the true area is equal to 0.5 ) and the reliability of the values of the AUC area.

The results of the two systems for the determination of specific IgE for mite and epidermal allergens by the Rida AllergyScreen and Euroline methods do not always agree very well due to the significant systematic divergence of indicators.

The results of determining specific $\operatorname{IgE}$ for individual allergens are in good agreement with each other; however, for both rabbit and guinea pig epidermal allergens, both methods do not agree with skin test results using the prick-test method, giving false-negative results. Further analysis of the consistency and diagnostic parameters of the methods for other allergen groups is necessary to summarize all the results of the study.

$\operatorname{IgE}$.

Стаття надійшла вредакцію 03.02.2020 р. 